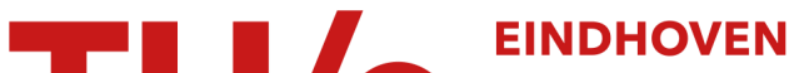 UNIVERSITY OF TECHNOLOGY
}

\section{Homologation of olefins with methane on transition-metals}

Citation for published version (APA):

Koerts, T., Leclercq, P. A., \& Santen, van, R. A. (1992). Homologation of olefins with methane on transitionmetals. Journal of the American Chemical Society, 114(18), 7272-7278. https://doi.org/10.1021/ja00044a043

DOI:

10.1021/ja00044a043

Document status and date:

Published: 01/01/1992

Document Version:

Publisher's PDF, also known as Version of Record (includes final page, issue and volume numbers)

Please check the document version of this publication:

- A submitted manuscript is the version of the article upon submission and before peer-review. There can be important differences between the submitted version and the official published version of record. People interested in the research are advised to contact the author for the final version of the publication, or visit the $\mathrm{DOI}$ to the publisher's website.

- The final author version and the galley proof are versions of the publication after peer review.

- The final published version features the final layout of the paper including the volume, issue and page numbers.

Link to publication

\section{General rights}

Copyright and moral rights for the publications made accessible in the public portal are retained by the authors and/or other copyright owners and it is a condition of accessing publications that users recognise and abide by the legal requirements associated with these rights.

- Users may download and print one copy of any publication from the public portal for the purpose of private study or research.

- You may not further distribute the material or use it for any profit-making activity or commercial gain

- You may freely distribute the URL identifying the publication in the public portal.

If the publication is distributed under the terms of Article $25 \mathrm{fa}$ of the Dutch Copyright Act, indicated by the "Taverne" license above, please follow below link for the End User Agreement:

www.tue.nl/taverne

Take down policy

If you believe that this document breaches copyright please contact us at:

openaccess@tue.nl

providing details and we will investigate your claim. 
it possible to take a set of generic skeletal force constants and use these for deriving structures with acceptable accuracy. As we have shown, the skeletal force constants are not generally transferable. If, however, one only wishes to obtain good structures of linear metallocenes, these force constants can be obtained for the metals in Table VIII by simply using those of ferrocene as a generic set, provided the correct equilibrium bond lengths and angles are used. This will probably apply even for somewhat strained linear metallocenes.

Acknowledgment. This work was supported by grants from the National Institutes of Health.

\title{
Homologation of Olefins with Methane on Transition Metals
}

\author{
Tijs Koerts, ${ }^{\dagger}$ Piet A. Leclercq, ${ }^{\dagger}$ and Rutger A. van Santen*, ${ }^{\dagger}$ \\ Contribution from the Schuit Institute of Catalysis, Department of Inorganic Chemistry and \\ Catalysis and Laboratory of Instrumental Analysis, Eindhoven University of Technology, \\ P.O. Box 513, 5600 MB Eindhoven, The Netherlands. Received December 27, 1991
}

\begin{abstract}
Alkylation of olefins using methane has been realized on transition metal catalysts. The main problem is to get methane dissociatively adsorbed together with an olefin. This is due to the difficult activation of the strong tetrahedral $\mathrm{C}-\mathrm{H}$ bonds of methane. To react methane with an olefin, a reaction sequence is used consisting of three steps. First methane is dissociatively adsorbed between 600 and $800 \mathrm{~K}$ on a reduced transition metal catalyst. After cooling, an olefin is coadsorbed at a temperature between 300 and $400 \mathrm{~K}$. Upon subsequent hydrogenation carbon-carbon bond formation occurs. The mechanism appears to be related to that occurring in the Fischer-Tropsch reaction. After hydrogenation the reaction cycle can be repeated. Methane addition to ethene, propene, and acetylene is demonstrated to occur using silica-supported ruthenium and cobalt catalysts. With ${ }^{13} \mathrm{CH}_{4}$ it was shown that propane and butane are formed both by self-homologation of ethene and propene, respectively, as well as by methane incorporation. Carbon scrambling according to the metathesis reaction is very slow.
\end{abstract}

\section{Introduction}

Methane homologation is of interest because of the many reactions that proceed via $\mathrm{CH}$ activation or carbon-carbon bond formation. Selective methane activation is difficult owing to the strong tetrahedral $\mathrm{C}-\mathrm{H}$ bonds that lack polarity, and the ease of consecutive reactions of the resulting $\mathrm{CH}_{x}$ groups.

Many different approaches have been developed in the activation of $\mathrm{C}-\mathrm{H}$ bonds in alkanes, using organo-metal systems, ${ }^{1-4}$ heterogeneous catalysts, ${ }^{5-7}$ gas-phase metal ions, ${ }^{8,9}$ homogeneous catalysis, ${ }^{10,11}$ or biochemical systems. ${ }^{12}$ On transition metals the mechanism of dissociative alkane adsorption has been extensively studied on single crystals. ${ }^{13-18}$ The activity for metal films to activate methane at temperatures starting at $400 \mathrm{~K}$ was demonstrated by Bond ${ }^{19}$ and Frennet ${ }^{20}$ from the methane-deuterium exchange reaction. Dissociative methane adsorption on transition metal catalysts has a relative low activation energy $(25-60 \mathrm{~kJ} /$ mol). ${ }^{21,22,56}$ However, to realize reasonable sticking coefficients for chemisorption, methane has to be activated. ${ }^{23-25}$ Dissociative methane adsorption at high temperature results mainly in unreactive coke formation. ${ }^{26,27}$ At mild conditions alkanes can be activated selectively with organo-metal complexes..$^{1-3,28}$ In such a reaction the metal center $(\mathrm{M})$ of the complex is able to interact with an alkane ( $\mathrm{R}-\mathrm{H})$ and can finally insert into the $\mathrm{C}-\mathrm{H}$ bond according to $\mathrm{R}-\mathrm{H}+\mathrm{M} \rightarrow \mathrm{R}-\mathrm{H} \cdots \mathrm{M} \rightarrow \mathrm{R}-\mathrm{M}-\mathrm{H}$.

Recently it has been found that hydrocarbons can be formed when methane is activated on a Ni single crystal ${ }^{2,30}$ or on supported metal catalysts. ${ }^{31-33}$ We have shown previously ${ }^{34,56}$ that when methane is activated thermally under mild conditions, a surface $\mathrm{C}_{1}$ intermediate can be generated that is able to produce $\mathrm{C}_{2}^{+}$ hydrocarbons upon hydrogenation. This occurs according to a Fischer-Tropsch synthesis type mechanism for carbon-carbon bond formation. ${ }^{35}$ O'Donohoe showed that the direct homologation of alkanes to a higher homologue is possible on tungsten catalysts. ${ }^{36,37}$ Also oxidative methylation of propene to butene has been reported ${ }^{38,39}$ on rare earth oxides.

Alkylation of olefins with methane to an alkane with one extra carbon atom is thermodynamically possible below $500 \mathrm{~K}$ in one

\footnotetext{
${ }^{+}$Schuit Institute of Catalysis.

t Laboratory of Instrumental Analysis.
}

step. ${ }^{40}$ This reaction has been found to occur using superacids as catalysts. ${ }^{41}$ Syskin and Mayer ${ }^{42}$ converted methane-ethene

(1) Crabtree, R. H. Chem. Rev. 1985, 85, 245.

(2) Bergman, R. G. Science 1984, 223, 4639.

(3) Shilov, A. E. Sov. Sci. Rev. Sect. B: Chem. Rev. 1982, B4, 71.

(4) Crabtree, R. H.; Holt, E. M.; Lavin, M.; Morekous, S. M. Inorg. Chem. 1985, 24, 1986.

(5) Baerns, M. Nachr. Chem. Tech. Lab. 1985, 33, 292.

(6) Pitchai; Klier, Catal. Rev.-Sci. Eng. 1968, 28, 13.

(7) Anderson, J. R. Appl. Catal. 1989, 47, 177.

(8) Irikura, K. K.; Beauchamp, J. L. J. Am. Chem. Soc. 1991, 113, 2769.

(9) Schwarz, H. Angew. Chem. 1991, 103, 837.

(10) Olah, G. A. Top. Curr. Chem. 1979, 80, 17.

(11) Olab, G. A.; Parker, D. G.; Yoneda, N. Angew. Chem. 1978, 90, 962.

(12) Patel, R. N.; Hou, C. T.; Laskin, A. I.; Felix, A. J. Appl. Biochem. $1982,4,175$

(13) Hamza, A. V.; Madix, R. J. Surf. Sci. 1987, 179, 25

(14) Szuromi, P. D.; Weinberg, W. H. Surf. Sci. 1985, 149, 226.

(15) Salmeron, M.; Somorjai, G. A. Surf. Sci. 1981, 85, 3835

(16) Arumainayagam, C. R.; McMaster, M. C.; Schoofs, G. R.; Madix, R. J. Surf. Sci. 1989, 222, 213.

(17) Trevor, D. J.; Cox, D. M.; Kaldor, A. J. Am. Chem. Soc. 1990, 112, 3742 .

(18) Brass, S. G.; Ehrlich, G. Phys. Rev. Lett. 1986, 57, 2532.

(19) Bond, G. C. In Catalysis by Metals; Academic Press: New York, 1962.

(20) Frennet, A. Catal. Rev.-Sci. Eng. 1974, 10, 37

(21) Tavares, M. T.; Bernardo, C. A.; Alstrup, I.; Rostrup-Nielson, J. R. J. Catal. 1986, I00, 545.

(22) Kuijpers, E. G. M.; Jansen, J. W.; Van Dillen, A. J.; Geus, J. W. Catal. 1981, 72, 75 .

(23) Schwarz, H. Acc. Chem. Res. 1989, 22, 282.

(24) Kay, B. D.; Coltrin, M. E. Surf. Sci. 1988, 198, L375.

(25) Rettner, C. T.; Pfnür, H. E.; Auerbach, D. J. Phys. Rev. Lett. 1985, $54,2716$.

(26) Sault, A. G.; Goodman, D. W. Adv. Chem. Phys. 1989, 76, 153.

(27) Van Der Zwet, G. P.; Hendriks, P. A. J. M.; Van Santen, R. A. Catal. Today 1989, 4, 365 .

(28) Chatt, J.; Davidson, J. M. J. Chem. Soc. 1965, 843.

(29) Yang, Q. Y.; Johnson, A. D.; Maynard, K. J.; Ceyer, S. T. J. Am. Chem. Soc. 1989, III, 8748.

(30) Ceyer, S. T. Science 1990, 249, 133. 


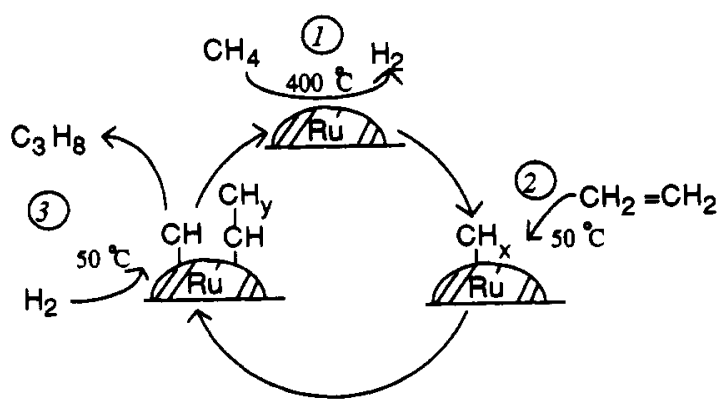

Figure 1. Reaction cycle for the stepwise conversion of methane and an olefin to a higher homologue.

mixtures to propane with a selectively of $40-60 \%$, using $\mathrm{TaF}_{5}-\mathrm{HF}$ at $40{ }^{\circ} \mathrm{C}$ and $1 \mathrm{MPa}$. Olah used superacids immobilized on alumina. ${ }^{43,44}$ At $70^{\circ} \mathrm{C}$ he reached a conversion of $38 \%$ with respect to ethene with a feed of $\mathrm{CH}_{4} / \mathrm{C}_{2} \mathrm{H}_{6}$ of $9: 1 \mathrm{~mol} / \mathrm{mol}$. Olah et al. ${ }^{45}$ showed in a reaction with ${ }^{13} \mathrm{CH}_{4}$ and ${ }^{12} \mathrm{C}_{2} \mathrm{H}_{4}$, under mild conditions, that ${ }^{13} \mathrm{C}^{12} \mathrm{C}^{12} \mathrm{C}$ propane is formed selectively, when the methane/ethene ratio is above 100 . Scurell ${ }^{46}$ indicated that these systems may not be truly catalytic, and some fluorine loss from the catalyst may occur during the reaction. Although the solid superacids ${ }^{47,48}$ used are much more environmental friendly than homogeneous acids, the use of HF to activate these systems remains a drawback.

On heterogeneous metal catalysts, the direct conversion of methane with ethene has not yet been realized. Indirect conversion routes have been proposed on nickel catalysts. Löffler et al..$^{49}$ performed a reaction with methane and cyclopentene to benzene and toluene at $310^{\circ} \mathrm{C}$. They repeated the reaction with ${ }^{13} \mathrm{CH}_{4}$ and were not able to detect incorporation of ${ }^{13} \mathrm{C}$ into the reaction products. However, when the nickel oxide catalyst was reduced at a higher temperature with ${ }^{13} \mathrm{CH}_{4}$ before the reaction, ${ }^{13} \mathrm{C}$ incorporation in benzene and toluene could be demonstrated to a modest extent. Ovales et al..$^{50}$ reported the conversion of methane with propene to isobutane at $350^{\circ} \mathrm{C}$ on a silica-supported nickel catalyst. They reduced the nickel oxide catalyst with methane at $600{ }^{\circ} \mathrm{C}$ for $8 \mathrm{~h}$ before the reaction. When the methane was substituted by nitrogen, the butane yield decreased, a process that is reversible. However, at $350^{\circ} \mathrm{C}$ the thermodynamics are not favorable for the reaction of methane and propene to butane.

(31) Shelimov, B. N.; Kazansky, V. B. J. Chem. Soc., Faraday Trans. I $1987,83,2381$.

(32) Tanaka, K.-I.; Yaegashi, I.; Aomoura, K. J. Chem. Soc., Chem. Commun. 1982, 938.

(33) Belgued, M.; Amariglio, H.; Pareja, P.; Amariglio, A.; Saint-Juste, J. Nature 1991, 352, 789 . 1281 .

(34) Koerts, T.; van Santen, R. A. J. Chem. Soc., Chem. Commun. 1991,

(35) Biloen, P.; Sachtler, W. M. H. Adv. Catal. 1981, 30, 165.

(36) O,Donohoe, C.; Clarke, J. K. A.; Rooney, J. J. J. Chem. Soc., Chem. Commun. 1979, 648.

(37) O,Donohoe, C.; Clarke, J. K. A. J. Chem. Soc., Faraday Trans. 1 $1980,76,345$.

(38) Sodosewa, T.; Matsabara, M.; Sato, S.; Nozak, F. Chem. Lett. 1987,

(39) Sofranko, J. A.; Leonard, J. J.; Jones, C. A. 1987, 103, 302.

(40) Scurrell, M. S. Appl. Catal. 1987, 32, 1.

(41) Siskin, M. J. Am. Chem. Soc. 1976, 98, 5413.

(42) Siskin, M.; Mayer, I. U.S. Patent 4094924,1987 (Exxon Research).

(43) Olah, G. A. U. S. Patent $4373109,1983$.

(44) Olah, G. A.; Schlosberg, R. H. J. Am. Chem. Soc. 1968, 90, 2726.

(45) Olah, G. A.; Felberg, J. D.; Lammertsma, K. J. Am. Chem. Soc. $1983,105,6529$.

(46) Scurrell, M. S. App. Catal. 1987, 34, 109.

(47) Arata, K. Adv. Catal. 1990, 37, 165.

(48) Olah, G. A. Angew. Chem., Int. Ed. Engl. 1973, 12, 173.

(49) Löffler, I. D.; Maier, W. F.; Andrade, J. G.; Thies, I.; Schleyer, P.

v. R. J. Chem. Soc., Chem. Commun. 1984, 1177.

(50) Ovales, C.; Leon, V.; Reyes, S.; Rosa, F. J. Catal. 1991, 129, 368.

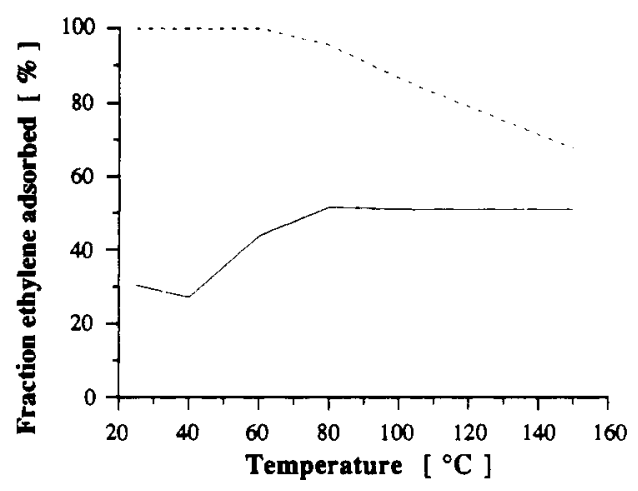

Figure 2. Fraction of ethene adsorbed on the reduced ruthenium catalyst before (solid line) and after methane adsorption at $450^{\circ} \mathrm{C}$ (dashed line) as a function of the ethene adsorption temperature.

Previously the incorporation of $\mathrm{CH}_{2}$ species from other molecules into ethene have been demonstrated using organo-metal complexes. ${ }^{51,52}$ Also from alkene addition experiments in the Fischer-Tropsch reaction, it is known that adsorbed olefins can undergo chain growth, resulting in longer hydrocarbons. ${ }^{53.54} \mathrm{~A}$ similar principle is applied here to incorporate surface carbon from methane into co-adsorbed olefins.

One of the main problems in the conversion of methane together with olefins on transition metals is the low sticking coefficient for dissociative methane adsorption compared to that of alkene adsorption. This prevents the simultaneous adsorption of methane and an olefin. To realize their co-adsorption, methane should not be adsorbed together with other reactants, but should be activated in a separate step. To achieve this, we developed a catalytic cycle in which the reactants are adsorbed separately at different temperatures (see Figure 1).

In the first step methane is thermally activated by dissociative adsorption on a reduced transition metal catalyst at a temperature between 200 and $550^{\circ} \mathrm{C}$. In the second step an olefin is co-adsorbed together with surface carbon from methane at a temperature between 20 and $100^{\circ} \mathrm{C}$. In the third step both hydrocarbon fragments are hydrogenated, forming a higher homologue.

This reaction sequence provides an overall reaction path for alkylation reactions using methane. Here we discuss the results for the reaction of methane with ethene, acetylene, and propene to form propane and butane, respectively. To prove that methane is actually incorporated into the reaction products, the reactions were repeated with ${ }^{13} \mathrm{C}$-labeled methane.

\section{Experimental Section}

Catalysts. A $5 \mathrm{wt} \%$ ruthenium catalyst and a $10 \mathrm{wt} \%$ cobalt catalyst were prepared by incipient wetness impregnation of Grace 332 type silica $\left(300 \mathrm{~m}^{2} / \mathrm{g}\right.$, pore volume $=1.65 \mathrm{~mL} / \mathrm{g}$, mesh size $\left.75-125\right)$ with an aqueous solution of $\mathrm{RuCl}_{3}$ (Drijfhout, Amsterdam) and $\mathrm{Co}\left(\mathrm{NO}_{3}\right)_{2} \cdot 6 \mathrm{H}_{2} \mathrm{O}$ (Merck), respectively. The catalysts were dried at $110^{\circ} \mathrm{C}$ and reduced before each experiment in situ between 400 and $550^{\circ} \mathrm{C}$. The ruthenium catalyst was treated in a synthesis gas flow $\left(\mathrm{H}_{2} / \mathrm{CO}=2\right.$ at $\left.100 \mathrm{kPa}\right)$ for 30 min at $250^{\circ} \mathrm{C}$ to increase its $\mathrm{CO}$ chemisorption capacity. The metal particle size as determined with transmission electron microscopy was 5.5 $\mathrm{nm}$ for the ruthenium and $8.5 \mathrm{~nm}$ for the cobalt catalyst. The active metal surface areas as derived from CO chemisorption (CO/Ru $=30 \%$ and $\mathrm{CO} / \mathrm{Co}=2.2 \%$ ) indicate incomplete reduction of the cobalt catalyst.

Experimental Conditions. For each experiment $300 \mathrm{mg}$ of the catalyst was placed in the reactor which consisted of a quartz tube (i.e. $10 \mathrm{~mm}$ ). Methane adsorption was performed at $450^{\circ} \mathrm{C}$ from a methane pulse to $90 \mathrm{~s}$ of $0.5 \% \mathrm{CH}_{4}$ in helium in a flow of $22.4 \mathrm{~mL} / \mathrm{min}$. After methane adsorption the catalyst was cooled to a temperature between 25 and 150 "C in helium as quickly as possible to avoid "ageing" of the surface carbon: typically the temperature was lowered within $100 \mathrm{~s}$ to $150^{\circ} \mathrm{C}$. Ethene, acetylene, or propene was adsorbed from pulses of $1.4 \mu \mathrm{mol}$ between 25 and $150{ }^{\circ} \mathrm{C}$. Subsequently, the adsorbed carbonaceous

(51) Sumner, C. E., Jr.; Riley, P. E.; Davis, R. E.; Petit, R. J. Am. Chem. Soc. 1980, 102, 1752 .

(52) Theopold, K. H.; Bergman, R. G. J. Am. Chem. Soc. 1981, $103,2489$.

(53) Jordan, D. S.; Bell, A. T. J. Catal. 1987, 107, 338.

(54) Smith, D. F.; Hawk, C. O.; Golden, P. L. J. Am. Chem. Soc. 1930 52,3221 


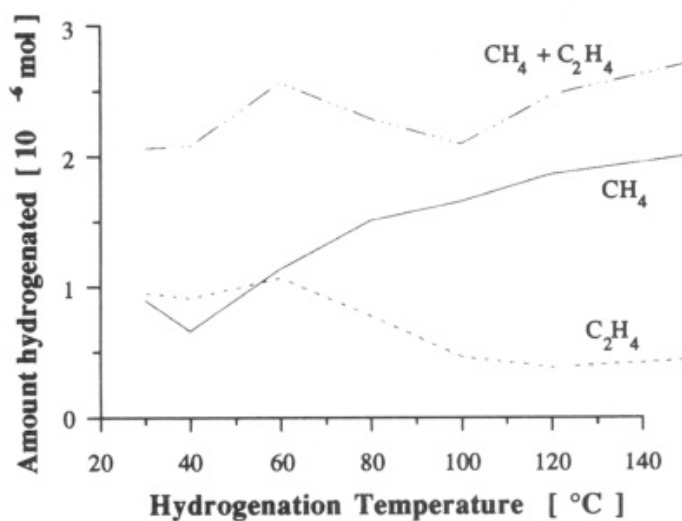

Figure 3. Total amount of carbonaceous material (in $\mu$ mol of $\mathrm{C}$ ) that can be hydrogenated after separate methane and ethene adsorption and their co-adsorption on the cobalt catalyst as a function of the hydrogenation temperature $\left(6.6 \mu \mathrm{mol}\right.$ of methane pulsed at $450^{\circ} \mathrm{C} ; 1.4 \mu \mathrm{mol}$ of ethene pulsed at the hydrogenation temperature).

surface species were hydrogenated in a flow of $22.4 \mathrm{~mL} / \mathrm{min}$ of hydrogen at ambient pressure at the same temperature as the olefin adsorption. After this hydrogenation the temperature was raised at a rate of 20 ${ }^{\circ} \mathrm{C} / \mathrm{min}$ to $550^{\circ} \mathrm{C}$ in the same hydrogen flow, to remove carbonaceous residues. After cooling to $450^{\circ} \mathrm{C}$ the cycle was repeated.

Analysis. During the first $2 \mathrm{~min}$ of hydrogenation, $15 \times 0.2 \mathrm{~mL}$ of the reaction gases were stored in a 16 loop multiposition valve (Chrompack type ST34). The stored reaction gases were injected in a GC (CP 9000 , Chrompack) and the reaction products were separated on a widebore plot $\mathrm{Q}$ column $(25 \mathrm{~m} \times 0.53 \mathrm{~mm}$ i.d. $)$.

For the experiments with labeled methane $\left(99 \%{ }^{13} \mathrm{CH}_{4}\right.$ from Cambridge Isotope Laboratories), the stored reaction gases were separated on the same column, which was connected (splitless) with a coupling unit (Graphpack-3D-Saulenverbinder from Gerstel) to a fused silica capillary of $2 \mathrm{~m}$ (i.d. $100 \mu \mathrm{m}$ ). This capillary was directly introduced in the ion chamber of a high resolution mass spectrometer. ${ }^{55}$ During the analyses the masses between 10 and $60 \mathrm{Da}$ were scanned every $1.5 \mathrm{~s}$. For each component about 10-20 mass spectra were taken to calculate the average peak ratios. From these peak ratios the fraction of each labeled product was calculated (see Appendix). From the mass spectra the position of the ${ }^{13} \mathrm{C}$ atom incorporated could be deduced.

\section{Results}

During the methane pulse at $450^{\circ} \mathrm{C}$ all the methane is adsorbed on the ruthenium catalyst, resulting in a carbon surface coverage of about $20 \%$. On the cobalt catalyst $60 \%$ of the methane is adsorbed. During the adsorption of ethene, acetylene, and propene between 25 and $150^{\circ} \mathrm{C}$, not all the reactants are adsorbed. A part of the olefin was autohydrogenated to the paraffin, while no olefin desorbed from the catalyst when adsorbed in small amounts. Especially when no methane was preadsorbed, alkane desorption was detected. Figure 2 compares the fractions of carbon adsorbed from a pulse of $1.4 \mu \mathrm{mol}$ of ethene on a reduced ruthenium catalyst, with a pulse after pre-adsorption of $6.6 \mu \mathrm{mol}$ of methane at $450^{\circ} \mathrm{C}$.

The fraction of adsorbed ethene is increased when surface carbon from methane is present on the catalyst surface. On the ruthenium catalyst more methane formation is observed during ethene adsorption than on cobalt. Above $100^{\circ} \mathrm{C}$ methane is the only product desorbing from the ruthenium catalyst, while mainly ethene desorbs from the cobalt catalyst.

After the adsorption steps on the ruthenium catalyst $6.6 \mu \mathrm{mol}$ of carbon from methane and $2.8 \mu \mathrm{mol}$ of carbon atoms from ethene (1 pulse) are present on the catalyst surface. For the cobalt catalyst these figures are 4.0 and $1.7 \mu \mathrm{mol}$, respectively, due to the incomplete adsorption from the pulses. The amount of adsorbed carbonaceous surface species, which can be hydrogenated at a particular hydrogenation temperature, is shown in Figure 3 for the cobalt catalyst.

At a hydrogenation temperature above $100^{\circ} \mathrm{C}$ most of the desorbing hydrocarbons originate from methane. Upon hydro-

(55) Leclercq, P. A.; Snijders, H. M. J.; Cramers, C. A.; Maurer, K. H.; Rapp, U. J. High Resolut. Chromatogr. 1989, I2, 651.

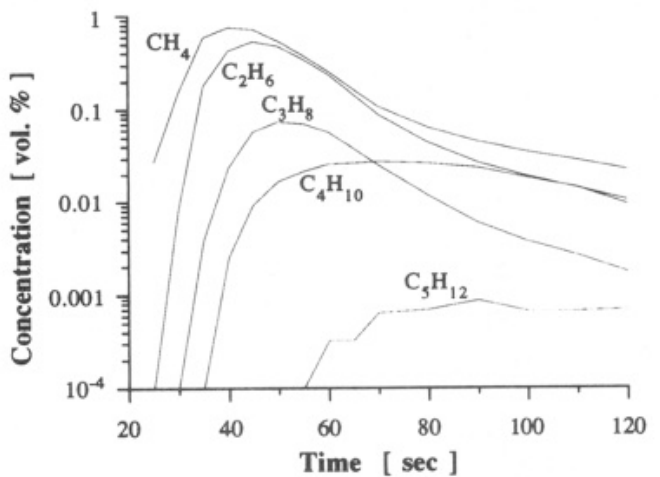

Figure 4. Products formed during the hydrogenation at $40^{\circ} \mathrm{C}$ of adsorbed methane $\left(6.6 \mu \mathrm{mol}\right.$ at $\left.450{ }^{\circ} \mathrm{C}\right)$ and ethene $\left(1.4 \mu \mathrm{mol}\right.$ at $\left.40^{\circ} \mathrm{C}\right)$ on the ruthenium catalyst at $40^{\circ} \mathrm{C}$ as a function of the hydrogenation time.
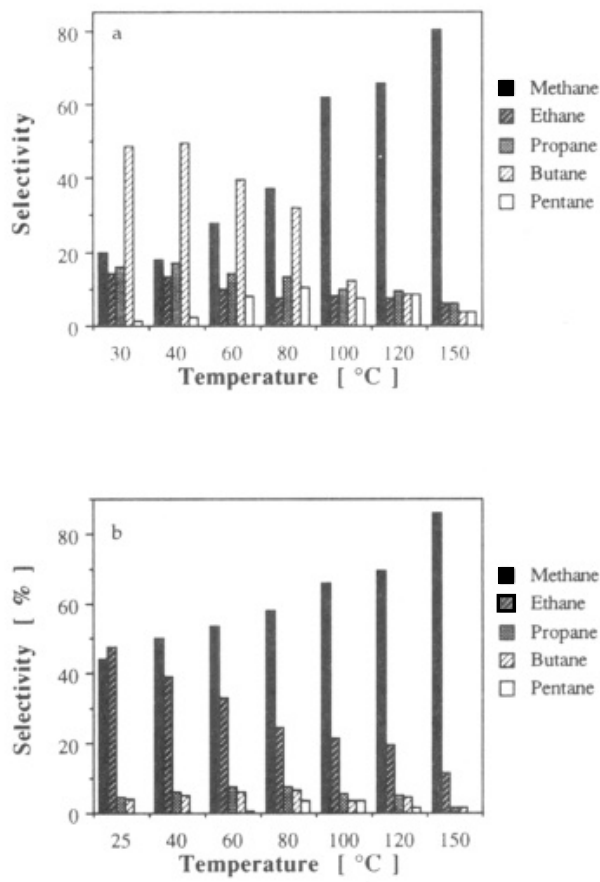

Figure 5. Product selectivity during the hydrogenation of adsorbed methane $\left(\right.$ at $450^{\circ} \mathrm{C}$ ) and ethene (1 pulse at stated temperature) as a function of the temperature: (a) cobalt, (b) ruthenium.

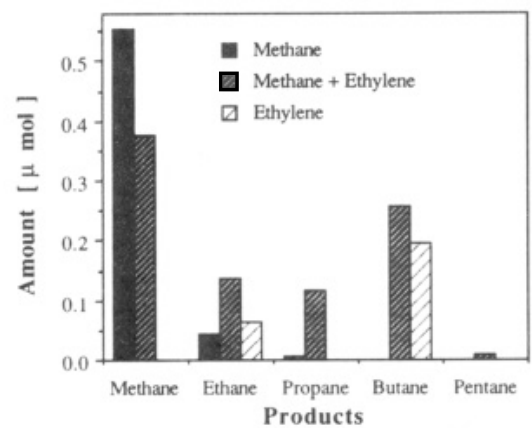

Figure 6. Product formation upon hydrogenation at $40^{\circ} \mathrm{C}$ of adsorbed methane $\left(T_{\text {ads }}=450^{\circ} \mathrm{C}\right)$, adsorbed ethene $\left(1\right.$ pulse at $\left.40^{\circ} \mathrm{C}\right)$, and their co-adsorption, on cobalt.

genation around $50^{\circ} \mathrm{C}$ the hydrocarbons are formed from about the same amounts of adsorbed ethene and methane.

Figure 4 depicts hydrocarbon formation from surface carbon as a function of the exposure time to hydrogen at $40^{\circ} \mathrm{C}$, during the first 2 min. By integrating these curves, the selectivity can be calculated. This is shown in Figure 5 and is expressed on the basis of carbon efficiency. For butane and pentane the iso and normal products are taken together. Mainly linear hydrocarbons are formed. 
Table I. Product Selectivity during Hydrogenation at $50^{\circ} \mathrm{C}$ of Adsorbed Olefins with and without Preadsorbed Methane at $450^{\circ} \mathrm{C}$

\begin{tabular}{|c|c|c|c|c|c|c|}
\hline adsorbates & methane & ethane & propane & butane $^{a}$ & pentane ${ }^{a}$ & $\begin{array}{l}\text { ratio } \\
i / n C_{4}\end{array}$ \\
\hline \multicolumn{7}{|c|}{ Ruthenium } \\
\hline $\mathrm{CH}_{4}+\mathrm{C}_{2} \mathrm{H}_{4}$ & 34 & 45 & 10 & 11 & 0.4 & 0.066 \\
\hline $\mathrm{C}_{2} \overrightarrow{\mathrm{H}}_{4}$ & 20 & 71 & 5 & 4.4 & 0 & 0.067 \\
\hline $\mathrm{CH}_{4}+\mathrm{C}_{2} \mathrm{H}_{2}$ & 34 & 36 & 14 & 16 & 0 & 0.056 \\
\hline $\mathrm{C}_{2} \mathrm{H}_{2}$ & 8.3 & 54 & 12 & 25 & 0.9 & 0.044 \\
\hline $\mathrm{CH}_{4}+\mathrm{C}_{3} \mathrm{H}_{8}$ & 24 & 29 & 36 & 10 & 1 & 0.082 \\
\hline $\mathrm{C}_{3} \mathrm{H}_{8}$ & 36 & 34 & 25 & 4.9 & 0.3 & 0.052 \\
\hline \multicolumn{7}{|c|}{ Cobalt } \\
\hline $\mathrm{CH}_{4}+\mathrm{C}_{2} \mathrm{H}_{4}$ & 10 & 12.5 & 17 & 53 & 6.5 & 0.030 \\
\hline $\mathrm{C}_{2} \mathrm{H}_{4}$ & 5.7 & 18 & 11 & 61 & 4.5 & 0.024 \\
\hline $\mathrm{CH}_{4}+\mathrm{C}_{2} \mathrm{H}_{2}$ & 33 & 21 & 16 & 26 & 4.8 & 0.072 \\
\hline $\mathrm{C}_{2} \mathrm{H}_{2}$ & 6.9 & 19 & 12 & 53 & 8.1 & 0.053 \\
\hline $\mathrm{CH}_{4}+\mathrm{C}_{3} \mathrm{H}_{8}$ & 11 & 3.2 & 54 & 26 & 6.1 & 0.164 \\
\hline $\mathrm{C}_{3} \mathrm{H}_{8}$ & 1.9 & 3.5 & 66 & 19 & 10 & 0.077 \\
\hline
\end{tabular}

${ }^{a}$ Sum of iso and $n$ product.

On cobalt, at a low ethene adsorption and hydrogenation temperature, the selectivity to butane is remarkably high due to ethene dimerization. When the hydrogenation temperature is raised, the methane selectivity increases owing to enhanced hydrogenolysis. The selectivity for the interesting reaction product propane is not a strong function of the temperature and has its maximum of $19 \%$ at $40^{\circ} \mathrm{C}$ on the cobalt catalyst.

Figure 6 compares the amount of products formed during hydrogenation, after separate methane and ethene adsorption and their co-adsorption. As previously demonstrated, ${ }^{34,56}$ surface carbon from methane alone can be hydrogenation to $\mathrm{C}_{2}{ }^{+}$hy. drocarbons. However, most of the dissociatively adsorbed methane reacts back toward methane. When ethene is co-adsorbed, the amount of methane formed as reduced and propane formation becomes significant. This indicates a reaction between adsorbed $\mathrm{C}_{1}$ species from methane and co-adsorbed ethene forming propane. The ability to form propane from adsorbed methane and ethene was tested to different metal catalysts. The order of the selectivity for propane formation is $\mathrm{Co}, \mathrm{Ru}>\mathrm{Pt}, \mathrm{Ni}, \mathrm{Rh}, \mathrm{Ir}>\mathrm{Re}, \mathrm{Fe}$. Here only the results of the cobalt and ruthenium catalyst will be discussed.

As indicated in Table I, propane formation is also possible from adsorbed ethene via hydrogenolysis and homologation, resulting in methane and propane. Such disproportionation reactions have been extensively studied by Basset and co-workers. ${ }^{57-60}$ To distinguish this reaction from methane incorporation into adsorbed ethene, experiments with ${ }^{13} \mathrm{C}$-labeled methane were performed. Therefore, $6.6 \mu \mathrm{mol}$ of ${ }^{13} \mathrm{CH}_{4}$ was pulsed at $450{ }^{\circ} \mathrm{C}$ over the catalyst and $5.2 \mu \mathrm{mol}$ of unlabeled ethene, acetylene, or propene was co-adsorbed at $50^{\circ} \mathrm{C}$. The product selectivities of the experiments performed under those conditions are shown in Table I.

The reactions were repeated using ${ }^{13} \mathrm{CH}_{4}$ and the products were analyzed for the presence of ${ }^{13} \mathrm{C}$ atoms. Of interest is the fraction of ${ }^{13} \mathrm{C}$ incorporated in the alkylated reaction products. This was measured for the different labeled isotopes and is shown in Table II.

The labeled ${ }^{13} \mathrm{C}$ atom from methane is added to adsorbed acetylene, ethene, and propene resulting in a product with one ${ }^{13} \mathrm{C}$ atom from methane and ${ }^{12} \mathrm{C}$ atoms from the olefin. This is shown by the underlined figures in Table II. As deduced from the fragment mass spectra, the labeled ${ }^{13} \mathrm{C}$ atom in the singly labeled products is the primary atom in propane and butane. The reaction products propane and butane are also formed exclusively from ${ }^{12} \mathrm{C}$ atoms from the adsorbed olefin due to auto-homolo-

(56) Koerts, T.; van Santen, R. A. J. Catal., accepted for publication. (57) Rodriguez, E.; Leconte, M.; Basset, J.-M.; Tanaka, K.; Tanaka, K.-J. J. Am. Chem. Soc. 1988, I10, 275.

(58) Rodriguez, E.; Leconte, M.; Basset, J.-M. J. Catal. 1991, 131, 457. (59) Rodriguez, E.; Leconte, M.; Basset, J.-M.; Tanaka, K.-I. J. Catal. 1989, $119,230$.

(60) Leconte, M.; Theolier, A.; Rojas, D.; Basset, J. M. J. Am. Chem. Soc. 1984, 106, 1141 .
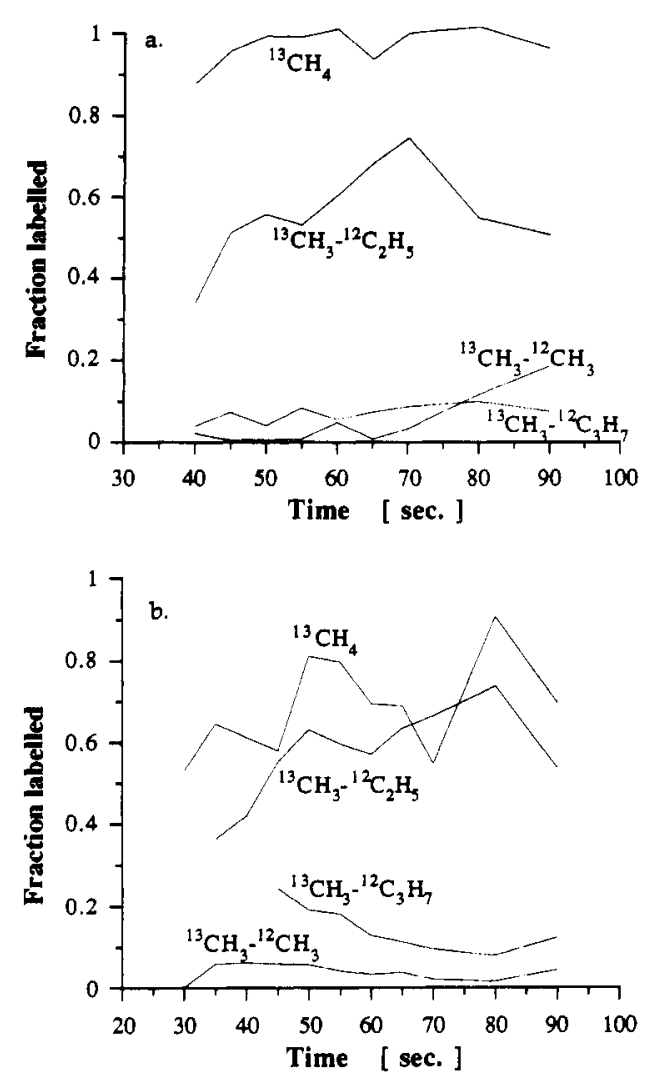

Figure 7. The fraction of each product consisting of one ${ }^{13} \mathrm{C}$ atom as a function of the hydrogenation time, for the stepwise reaction of $\left[{ }^{13} \mathrm{C}\right]$ methane with unlabeled ethene: (a) cobalt, (b) ruthenium.

gation. Apparently, ${ }^{13} \mathrm{C}_{1}$ surface species from methane compete with ${ }^{12} \mathrm{CH}_{x}$ species generated by olefin hydrogenolysis for carbon incorporation.

Figure 7 shows the fraction of products containing one ${ }^{13} \mathrm{C}$ atom, as a function of the hydrogenation time.

The fraction of ${ }^{13} \mathrm{C}$ in propane is a slight function of the hydrogenation time. The fraction of ${ }^{13} \mathrm{C}$ in the reaction product increases a little as a function of time in nearly all the experiments with labeled methane.

\section{Discussion}

Adsorption. Dissociative methane adsorption can result in three types of surface carbonaceous species. They differ in their hydrogenation temperature ${ }^{61,62}$ and have been identified as carbidic $\left(C_{\alpha}\right)$, amorphous $\left(C_{\beta}\right)$, and graphitic $\left(C_{\gamma}\right)$ with $A_{E S}^{63,64}$ and NMR. ${ }^{65}$ Under the particular methane adsorption conditions used here, about $60 \%$ of the surface carbon species from methane on $\mathrm{Ru}$ and $40 \%$ on Co consist of reactive carbidic $\mathrm{C}_{\alpha}$ that is able to react below $100^{\circ} \mathrm{C}$ with hydrogen to hydrocarbons. The less reactive $C_{\beta}$ and unreactive $C_{\gamma}$ species can be removed during temperature-programmed hydrogenation. $\mathrm{Up}$ to a hydrogenation temperature of about $240^{\circ} \mathrm{C}$ some $\mathrm{C}_{2}{ }^{+}$hydrocarbon formation is observed, while at higher temperatures only methane is formed.

The differences in adsorption probability of olefins, with and without the pre-adsorption of methane (Figure 2), might suggest a direct interaction between adsorbed surface carbon and the co-adsorbed olefin. However, concerning the ethene adsorption mechanism, this appears not to be the case. The mechanism of adsorption of ethene on reduced transition metals has been studied on single crystals. ${ }^{66-68}$ Chemisorbed ethene loses one or more

(61) Koerts, T.; Van Santen, R. A. Catal. Lett. 1990, 6, 49

(62) Koerts, T.; Van Santen, R. A. J. Mol. Catal., accepted for publication.

(63) Houston, J. E.; Peebles, D. E.; Goodman, D. W. J. Vac. Sci. Technol. A 1983, 1,995

(64) Goodman, D. W.; Kelley, R. D.; Madey, T. E.; Yates, Y. T., Jr. J. Catal. 1980, 63, 226.

(65) Duncan, T. M.; Winslow, P.; Bell, A. T. J. Catal. 1985, 93, 1. 
Table II. Relative Frequency of Different ${ }^{13} \mathrm{C}$ Isotopically Labeled Reaction Products ${ }^{a}$

\begin{tabular}{|c|c|c|c|c|c|c|c|c|c|c|c|}
\hline \multirow[b]{2}{*}{ precursor } & \multirow{2}{*}{$\begin{array}{l}\text { methane } \\
{ }^{13} \mathrm{CH}_{4}\end{array}$} & \multicolumn{3}{|c|}{ ethane } & \multicolumn{3}{|c|}{ propane } & \multicolumn{4}{|c|}{$n$-butane } \\
\hline & & $\overline{{ }^{12} C_{2}}$ & ${ }^{12} \mathrm{C}-{ }^{13} \mathrm{C}$ & $\sqrt{13} \mathrm{C}_{2}$ & ${ }^{12} C_{3}$ & ${ }^{12} \mathrm{C}_{2}-{ }^{13} \mathrm{C}$ & ${ }^{12} \mathrm{C}-{ }^{13} \mathrm{C}_{2}$ & ${ }^{12} \mathrm{C}_{4}$ & ${ }^{12} \mathrm{C}_{3}-{ }^{13} \mathrm{C}$ & ${ }^{12} \mathrm{C}_{2}-{ }^{13} \mathrm{C}_{2}$ & ${ }^{12} \mathrm{C}-{ }^{13} \mathrm{C}_{3}$ \\
\hline & & & & & & Cobalt & & & & & \\
\hline acetylene & 95 & 83 & 2 & 12 & 41 & $\underline{51}$ & 0.02 & 79 & 14 & 5.2 & 2.2 \\
\hline ethene & 99 & 89 & 0 & 12 & 40 & 58 & 0.7 & 82 & 8.2 & 8.8 & 0.6 \\
\hline propene & 98 & 61 & 9 & 30 & 98 & 1.1 & 0.3 & 26 & $\underline{73}$ & 0.7 & 0.4 \\
\hline & & & & & & uthenium & & & & & \\
\hline acetylene & 94 & 88 & 4 & 8 & 51 & 47 & 1 & 85 & 11 & 4.4 & 0 \\
\hline ethene & 75 & 95 & 1 & 4 & 36 & $\underline{62}$ & 1.7 & 81 & 10 & 7.8 & 0.6 \\
\hline propene & 92 & 89 & 5 & 6 & 93 & 5.3 & 0.8 & 50 & 47 & 1.9 & 1.3 \\
\hline
\end{tabular}

${ }^{a}$ The results are weighted averages of the analyses of 6 to 13 loops. For calculations, see Appendix.

hydrogen atoms at temperatures above room temperature and is adsorbed like an ethylidyne $\left(\mathrm{CCH}_{3}\right)$, vinylidyne $\left(\mathrm{CCH}_{2}\right)$, or acetylide $(\mathrm{CCH})$ surface species. ${ }^{69}$ Because of the low temperature, the resulting surface hydrogen does not desorb but is used to hydrogenate other ethene molecules to ethane in an auto-hydrogenation reaction. The desorbing products consist of only methane and ethene; no trace of ethene was detected at the low ethene surface concentrations applied. When surface carbon from methane is present, the free forming hydrogen atoms from ethene are used to form $\mathrm{CH}_{x}$ surface species, instead of forming ethane from ethene. This decreases the formation of ethane and enhances the fraction of ethene that remains adsorbed.

Hydrogenation. The optimum temperature for hydrogenation of surface carbon depends on the amount of surface species that can be hydrogenated and on the product selectivity (Figures 3 , 4 , and 5). In general, the selectivity to propane and butane is high at low hydrogenation temperature, while at a hydrogenation temperature about $80^{\circ} \mathrm{C}$, more surface carbon can be hydrogenated. The optimum hydrogenation temperature is about 50 ${ }^{\circ} \mathrm{C}$. This is the temperature at which the experiments with labeled methane were done. At this temperature about equimolar amounts of adsorbed methane and olefins are hydrogenated on both catalyst systems. These amounts correspond to a carbon surface coverage of about $11 \%$ for both methane and alkene (normalized on the $\mathrm{CO}$ chemisorption capacity). At higher carbon surface coverages, surface carbon becomes less reactive because of the enhanced formation of $\mathrm{C}_{\beta}{ }^{56}$

Table I shows that, upon hydrogenation of adsorbed olefins, the selectivity for methane formation is higher on ruthenium than on cobalt. This result is in agreement with earlier observations, ${ }^{70,71}$ where it has been shown that ruthenium is the most active metal for hydrogenolysis. At $50^{\circ} \mathrm{C}$ the clean surface of the well-reduced ruthenium catalyst has a remarkably high activity for hydrogenolysis.

The higher rate of hydrogenolysis on ruthenium does not lead to an enhanced selectivity for homologation compared to cobalt. At the hydrogenating conditions $\left(50^{\circ} \mathrm{C}\right.$ and $100 \mathrm{kPa}$ of $\left.\mathrm{H}_{2}\right)$, the thermodynamics are in favor of methane formation instead of homologation.

Cobalt has a high selectivity of $64 \%$ for ethene dimerization, whereas this is only $4 \%$ on ruthenium. The selectivity for dimerization of acetylene is higher than that of ethene on ruthenium. This supports previous suggestions on the same catalyst indicating that the recombination of carbon surface fragments is most effective from hydrogen-deficient adsorbates. ${ }^{72}$

Experiments with Labeled Methane. Table II shows that labeled methane can be incorporated into co-adsorbed olefins, resulting in the reaction products propane and butane. This demonstrates alkylation of olefins with methane according to the reaction cycle

(66) Hills, M. M.; Parameter, J. E.; Mullins, C. B.; Weinberger, W. H. J. Am. Chem. Soc. 1986, 108, 3554.

(67) Zaera, F. J. Am. Chem. Soc. 1989, 111, 4240.

(68) Hills, M. M.; Parameter, J. E.; Weinberg, W. H. J. Am. Chem. Soc.

$1986,108,7215$.

(69) Salmerön, M.; Somorjai, G. A. J. Phys. Chem. 1982, 86, 341.

(70) Sinfelt, J. H. Adv. Catal. 1973, 23, 91.

(71) Gao, S.; Schmidt. L. D. J. Catal. 1989, 115, 356

(72) Koerts, T.; Van Santen, R. A. J. Mol. Catal. 1991, 70, 119.

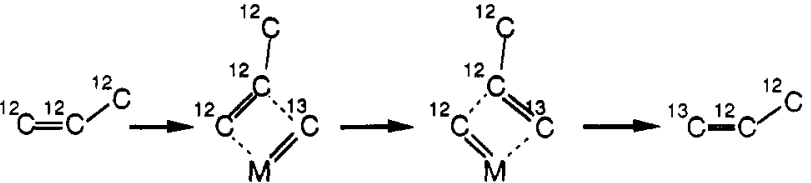

Figure 8. Metathesis mechanism according to which $\left[{ }^{12} \mathrm{C}\right]$ propene may exchange a carbon atom with a ${ }^{13} \mathrm{C}$ from methane. The hydrogen atoms are not drawn ( $M$ is an active center consisting of one or more metal atoms).

in Figure 2. However, 30-50\% of the homologated olefins contain only ${ }^{12} \mathrm{C}$, and thus originate entirely from the initial olefins. This means that $\mathrm{C}-\mathrm{C}$ bond formation from $\mathrm{C}_{1}$ intermediates, generated from methane deposition or from alkene hydrogenolysis, occurs with about the same probability. Because the surface concentrations of the reacting methane and olefin fragments are the same, this indicates that the $C_{1}$ intermediates involved are very similar. They probably both form carbon-carbon bonds according to a Fischer-Tropsch-like reaction mechanism.

Some additional experiments were done to study the influence of the olefin hydrogenation temperature and the ratio of adsorbed methane/olefin. When less ethene was pulsed and the ethene adsorption and hydrogenation temperature were decreased to 25 ${ }^{\circ} \mathrm{C}$, the fraction of singly labeled ${ }^{13} \mathrm{C}$ propane increased to $76 \%$ on the ruthenium catalyst. Because of the lower temperature, the rate of hydrogenolysis decreases. This reduces the amount of ${ }^{12} C_{1}$ surface fragments, resulting in an enhanced fraction of propane from $\left[{ }^{13} \mathrm{C}\right]$ methane and $\left[{ }^{12} \mathrm{C}\right]$ ethene. The rate of hydrogenolysis is much lower on the cobalt catalyst. At $25^{\circ} \mathrm{C}$ no methane formation is observed when adsorbed ethene is hydrogenated. However, in the reaction of ${ }^{13} \mathrm{CH}_{4}$ with ethene, only $66 \%$ of the propane formed is singly labeled, while still $30 \%$ consists of only ${ }^{12} \mathrm{C}$ from ethene. This suggests that either ethene reacts toward propane and methane, or that singly labeled propane can exchange its ${ }^{13} \mathrm{C}$ carbon atom with a ${ }^{12} \mathrm{C}$ from ethene, resulting in ${ }^{12} \mathrm{C}-{ }^{13} \mathrm{C}$ ethene. The latter compound does not appear in the gas phase, but can be dimerized to singly or doubly labeled butane, which butanes are formed in low fractions.

The absence of singly ${ }^{13} \mathrm{C}$-labeled propane, when propene is co-adsorbed with labeled methane, and the absence of singly labeled ethane, when ethene is co-adsorbed, indicate that the metathesis reaction (see Figure 8 ) or other routes for carbon scrambling are slow compared to hydrogenolysis, carbon-carbon bond formation, and hydrogenation, on ruthenium.

The metathesis reaction between ${ }^{13} \mathrm{C}$ surface carbon and an olefin as proposed in Figure 8 does not occur and is therefore very slow compared to hydrogenolysis and carbon-carbon bond formation at $50^{\circ} \mathrm{C}$ and $100 \mathrm{kPa}$ of $\mathrm{H}_{2}$. Hence, nonlabeled butane is not formed from two propene molecules via metathesis, resulting in ethene and butene, but via hydrogenolysis and homologation. This result is in agreement with measurements of Tanaka et al..$^{73-76}$

(73) Tanaka, K.; Tanaka, K.-I. J. Chem. Soc., Chem. Commun. 1984, 1626.

(74) Tanaka, K.; Tanaka, K.-I.; Takeo, H.; Matsumura, C. J. Chem. Soc., Chem. Commun. 1986, 33. 1859. 
Table III. Percentage of Singly ${ }^{13} \mathrm{C}$-Labeled Iso and $n$-Butane

\begin{tabular}{cccccc}
\hline & \multicolumn{2}{c}{ cobalt } & & \multicolumn{2}{c}{ ruthenium } \\
\cline { 2 - 3 } \cline { 5 - 6 } precursors & $i-\mathrm{C}_{4}$ & $n-\mathrm{C}_{4}$ & & $i-\mathrm{C}_{4}$ & $n-\mathrm{C}_{4}$ \\
\hline${ }^{13} \mathrm{CH}_{4}+\mathrm{C}_{2} \mathrm{H}_{4}$ & $50-70$ & 14 & $60-80$ & 15 \\
${ }^{13} \mathrm{C}_{4}+\mathrm{C}_{3} \mathrm{H}_{6}$ & $40-80$ & 73 & & $30-50$ & 45 \\
\hline
\end{tabular}

on $\mathrm{MoO}_{x}$ catalysts. They demonstrated that surface carbon species involved in metathesis are different from the intermediates active in the Fischer-Tropsch reaction. The hydrocarbon isomerization reactions as reported on platinum ${ }^{77-79}$ are relatively slow on these catalysts.

It is possible to calculate the selectivity for hydrogenolysis and homologation of the adsorbed olefins in the presence of ${ }^{13} \mathrm{C}$ from methane from Tables I and II, by not taking into account the molecules containing ${ }^{13} \mathrm{C}$ atoms. The selectivity pattern appeared to be about the same as that of the solely adsorbed olefins. This indicates that the selectivities for hydrogenolysis, homologation, and dimerization are not influenced by surface carbon species from methane. In particular, for hydrogenolysis this was unexpected, because surface carbon should decrease the amount of free metal ensembles necessary for hydrogenolysis. Apparently the carbon surface coverages applied $(\sim 20 \%)$ are too low to change the mentioned rates significantly.

Isobutane/n-Butane Ratio. During the hydrogenation of carbonaceous intermediates from methane and olefins at $50^{\circ} \mathrm{C}$, the selectivity for butane formation varies from 5 to $60 \%$. Most of the butane is $n$-butane but also some isobutane is formed. In relation to isobutane formation, differences in the mechanistic routes of formation are of interest. A comparison of the fraction of ${ }^{13} \mathrm{C}$ in $n$-butane and isobutane in the hydrogenation reaction of adsorbed ${ }^{13} \mathrm{C}$ with ethene or propene is given in Table III.

Owing to the low selectivity, the fraction of ${ }^{13} \mathrm{C}$ in isobutane could not be determined with great accuracy. The incorporation of ${ }^{13} \mathrm{C}$ in isobutane formed from ethene is more dominant than in $n$-butane, because the latter is mainly formed by dimerization of ethene. Iso- and $n$-butane are not in a dynamic equilibrium, and their routes of formation are probably different. For the incorporation of ${ }^{13} \mathrm{C}$ in propene to form iso- and $n$-butane, no significant differences were found. This indicates that surface carbon generated from propene dissociation reacts similarly as surface carbon from methane.

When the carbon surface coverage is higher, adsorbed propene species react to a larger extent to isobutane: the ratio of iso-/ $n$-butane increases from 0.08 to 0.16 on cobalt (see Table I). This indicates that in the formation of isobutane a surface carbon atom is involved. The ratio of iso-/ $n$-butane from only surface carbon from methane is higher $(0.30)$ than that with co-adsorbed propene. Adsorbed propene reacts mainly toward $n$-butane.

The ratio of iso- $/ n$-butane is even lower on the ruthenium than on the cobalt catalyst. These low ratios are typical distributions of the Fischer-Tropsch (FT) synthesis in which ruthenium mainly produces the linear alkanes. ${ }^{80,81}$ It indicates that the mechanism of carbon-carbon bond formation between ethene and carbidic surface carbon from methane is very similar to that occurring in FT synthesis. In the FT reaction, added ethene in the feed has been shown to incorporate into hydrocarbons. ${ }^{53,54,82,83}$ The formation of adsorbed ethene has been suggested to be one of the slow steps for chain propagation, and therefore added ethene can serve as chain growth initiator. ${ }^{84,85}$ Our results are in agreement

(76) Tanaka, K.; Tanaka, K.-I. J. Chem. Soc., Chem. Commun. 1983, 259. (77) Sachtler, W. M. H. Faraday Discuss. Chem. Soc. 1981, 72, 7

(78) Garin, F.; Gault, F. G. In Chemistry and Chemical Engineering of Catalytic Processes; Prins, R., Schuit, G. C. A., Eds.; Sijthoff \& Noordhoff: Alphen a.d. Rijn, 1980; p 351.

(79) Gault, F. G. Adv. Catal. 1981, 30,1.

(80) McCandlish. L. E. J. Catal. 1983, 83, 362

(81) Joyner, R. W. Catal. Lett. 1988, $1,307$.

(82) Morris, S. R.; Moyes, R. B.; Wells, P. B.; Whyman, R. J. Catal. 1985, 96,23

83) Adesina, A. A.; Hudgins, R. R.; Silveston, P. L. Appl. Catal. 1990, 62,295 .

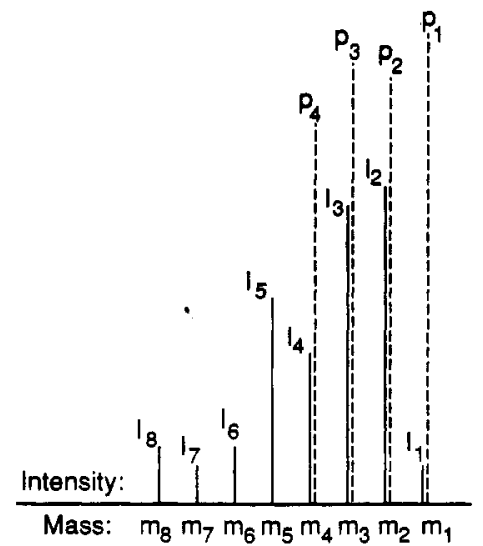

Figure 9. Reference mass spectrum with intensities $I_{i}$ at mass $m_{i}$. The intensities of the peaks $p_{1}$ to $p_{4}$ from the labeled mixture at mass $m_{1}$ to $m_{4}$ are shown by the dashed lines.

with these observations: more surface carbon from methane undergoes carbon-carbon bond formation when ethene is co-adsorbed.

Yields. The overall yield for the reaction of methane and ethene to propane according to the proposed reaction cycle depends on the fraction of methane adsorbed, fraction of ethene adsorbed, amount of surface carbon hydrogenated at the hydrogenation temperature, selectivity to propane, and the fraction of propane consisting of only one ${ }^{13} \mathrm{C}$ atom from methane. Taking all these factors into account, the yield for the reaction of ${ }^{13} \mathrm{CH}_{4}$ with adsorbed ethene is $2.8 \%$ on the basis of pulsed methane and $4.5 \%$ on the basis of pulsed ethene on the ruthenium catalyst. The ethene yield can be increased by increasing the methane/ethene ratio. The yield on methane basis is about three times higher than that in superacid catalyzed alkylation, ${ }^{45}$ while it is lower by a factor of $\sim 6$ on an ethene basis.

\section{Conclusions}

The incorporation of methane into alkenes in the presence of hydrogen on transition metal catalysts can be performed using a reaction cycle in which methane is separately adsorbed. In this way methane can be used as an alkylating agent. This is dem. onstrated for the incorporation of methane into ethene, acetylene, and propene. The reaction products propane and butane can be formed also via auto-homologation. The comparable reaction rates of self-homologation and methane incorporation indicate that the $\mathrm{C}_{1}$ intermediates involved are similar; they are both related to the $\mathrm{CH}_{x}$ fragments active in the Fischer-Tropsch reaction.

The exchange of carbon atoms according to a metathesis reaction does not occur on the ruthenium catalyst, while it cannot be excluded on cobalt. The cobalt catalyst has a remarkably high selectivity for dimerization of adsorbed ethene.

\section{Appendix}

Calculation of Isotropic Distributions from Mass Spectra. An alkane with $n$ carbon atoms either ${ }^{12} \mathrm{C}$ or labeled ${ }^{13} \mathrm{C}$, can have $n+1$ differently labeled isotopes: unlabeled, singly ${ }^{13} \mathrm{C}$ labeled, up to $n$ times labeled alkane (not taking into account the different positions of the ${ }^{13} \mathrm{C}$ atom). It is possible to calculate the fraction of each differently labeled isotope from a mass spectrum. This is not trivial because the mass spectrum of the unlabeled alkane disturbs an easy calculation. ${ }^{86}$ Here we present an algorithm to deduce these fractions from the mass spectrum. Propane is taken as an example, while problems are identical for $\mathrm{C}_{n}$ with $n>3$. Propane can have four types of different labeled isotopes: ${ }^{12} \mathrm{C}_{3}$, ${ }^{12} \mathrm{C}_{2}-{ }^{13} \mathrm{C},{ }^{12} \mathrm{C}-{ }^{13} \mathrm{C}_{2}$, and ${ }^{13} \mathrm{C}_{3}$. Their relative frequency are indicated with $f_{1}$ to $f_{4}$. To calculate $f_{1}$ to $f_{4}$ one has to know the

(84) Mims, C. A.; McCandlish, L. E. J. Phys. Chem. 1987, 91, 929. (85) Mims, C. A.; McCandlish, L. E.; Melchior, M. T. Catal. Lett. 1988, 1,121

(86) Millard, B. J. In Quantitative Mass Spectrometry; Ad. Heyden \& Son Ltd.: London, 1978. 
reference mass spectrum of unlabeled propane and that of the labeled mixture. It is assumed that the "isotope effect" ${ }^{n 6}$ does not influence the fragmentation process. A part of the reference spectrum $m_{1}$ to $m_{7}$ have relative intensities $I_{1}$ to $I_{7}$ as shown in Figure 9.

From the measured peaks $p_{1}$ to $p_{4}$ of the labeled mixture, one can calculate the fractions $f_{1}$ to $f_{4}$. Each of the measured intensities $n$ is the sum of the fraction multiplied by the intensity of the unlabeled component. This follows from Figure 9 and is shown in eq 1 :

$$
p_{1}=I_{1} f_{1}+I_{2} f_{2}+I_{3} f_{3}+I_{4} f_{4}
$$

This can be written in matrix form for all the four peaks measured:

$$
\left(\begin{array}{l}
P_{1} \\
p_{2} \\
p_{3} \\
P_{4}
\end{array}\right)=\left(\begin{array}{llll}
I_{1} & I_{2} & I_{3} & I_{4} \\
I_{2} & I_{3} & I_{4} & I_{5} \\
I_{3} & I_{4} & I_{5} & I_{6} \\
I_{4} & I_{5} & I_{6} & I_{7}
\end{array}\right)\left(\begin{array}{l}
f_{1} \\
f_{2} \\
f_{3} \\
f_{4}
\end{array}\right)
$$

The fractions $f_{1}$ to $f_{4}$ are calculated from the inverse matrix $\left(\mathbf{M}^{-1}\right)$ containing the intensities $I_{1}$ to $I_{7}$ from eq 2 :

$$
\vec{f}=\mathbf{M}^{-1} \cdot \vec{p}
$$

Finally the fractions $f_{i}(i=1-4)$ are normalized according to:

$$
f_{i}=f_{i} / \sum_{i=1}^{4} f_{i}
$$

In principle, from any $n$ peaks from the mass spectrum of $\mathrm{C}_{n} \mathrm{H}_{2 n+2}$ this calculation can be performed; however, experimental errors are relatively low when differences between intensities in the reference spectrum are large. Therefore, we used the masses $m / z 44-47$ for propane, $m / z 30-32$ for ethane, and $m / z 31-29$ for the $\mathrm{C}_{2}$ fragment of propane. By comparing the analyses of the $C_{2}$ and the $C_{3}$ fragments of propane, it could be concluded that in the singly labeled product mainly the primary atom is labeled.

Acknowledgment. We gratefully thank Henri M. J. Snijders for his assistance at the high resolution mass spectrometer and Jef L. Willigers for his experimental help at the microflow reactor. The Dutch Organisation of Fundamental Chemical Research, SON, is acknowledged for its financial support.

Registry No. $\mathrm{CH}_{4}, 74-82-8 ; \mathrm{C}_{2} \mathrm{H}_{4}, 74-84-0 ; \mathrm{C}_{2} \mathrm{H}_{2}, 74-86-2 ; \mathrm{C}_{3} \mathrm{H}_{8}$, 115-07-1; $\mathrm{CH}_{3} \mathrm{CH}_{2} \mathrm{CH}_{3}, 74-98-6 ; \mathrm{CH}_{3}\left(\mathrm{CH}_{2}\right)_{2} \mathrm{CH}_{3}, 106-97-8 ; \mathrm{CH}_{3}(\mathrm{C}-$ $\left.\mathrm{H}_{2}\right)_{3} \mathrm{CH}_{3}, \quad 109-66-0 ;{ }^{13} \mathrm{CH}_{4}, 6532-48-5 ; \mathrm{CH}_{3}{ }^{13} \mathrm{CH}_{3}, 6145-17-1$; ${ }^{13} \mathrm{CH}_{3}{ }^{13} \mathrm{CH}_{3}, 52026-74-1 ; \mathrm{CH}_{3} \mathrm{CH}_{2}{ }^{13} \mathrm{CH}_{3}, 17251-65-9 ; \mathrm{CH}_{3}{ }^{13} \mathrm{CH}_{2} \mathrm{CH}_{3}$, 17251-62-6; $\mathrm{CH}_{3}\left(\mathrm{CH}_{2}\right)_{2}{ }^{13} \mathrm{CH}_{3}, 22612-53-9 ; \mathrm{CH}_{3} \mathrm{CH}_{2}{ }^{13} \mathrm{CH}_{3}{ }^{13} \mathrm{CH}_{3}$, 141556-21-0; $\mathrm{CH}_{3}\left({ }^{13} \mathrm{CH}_{2}\right)_{2}{ }^{13} \mathrm{CH}_{3}, 141556-22-1$; ruthenium, 7440-18-8; cobalt, $7440-48-4$

\title{
Aerobic Oxidative Dehydrogenations Catalyzed by the Mixed-Addenda Heteropolyanion $\mathrm{PV}_{2} \mathrm{Mo}_{10} \mathrm{O}_{40}{ }^{5-}$ : A Kinetic and Mechanistic Study
}

\author{
Ronny Neumann* and Michal Levin
}

Contribution from the Casali Institute of Applied Chemistry, Graduate School of Applied Science and Technology, The Hebrew University of Jerusalem, Jerusalem, Israel 91904. Received December 31, 1991

\begin{abstract}
The aerobic oxidative dehydrogenation of $\alpha$-terpinene to $p$-cymene catalyzed by the mixed-addenda heteropolyanion $\mathrm{PV}_{2} \mathrm{Mo}_{10} \mathrm{O}_{40}$ s- has been used to investigate the oxidation mechanism catalyzed by this class of compounds. The kinetics of the reaction show it to be zero order in $\alpha$-terpinene, first order in dioxygen, and second order in the heteropolyanion catalyst. The kinetic results along with the use of UV-vis, ESR, ${ }^{31} \mathrm{P}$ NMR, and IR spectroscopy have enabled the formulation of a reaction scheme involving the formation of a stable substrate-catalyst complex in the catalyst reduction (substrate oxidation) stage and a $\mu$-peroxo catalyst intermediate in the catalyst reoxidation stage where dioxygen is reduced to water in a four-electron redox reaction.
\end{abstract}

\section{Introduction}

Since the discovery in 1826 by Berzelius of the first heteropoly compound, ${ }^{1}$ the vast field of heteropolyanion chemistry has been centered mostly around the preparation, structure, properties, and analytical chemistry applications of these compounds. ${ }^{2}$ Heteropoly compounds are soluble polyoxoion salts of anions having the general formula $\left[\mathrm{X}_{x} \mathrm{M}_{m} \mathrm{O}_{y}\right]^{q-}(x \leq m)$, where $\mathrm{X}$ is a heteroatom and $M$ is an addenda atom. A common and important class of these salts and those used in the majority of catalytic applications is the Keggin compounds (Figure 1), with the general formula $\mathrm{XM}_{12} \mathrm{O}_{40^{q}}(1)(\mathrm{X}=\mathrm{P}, \mathrm{Si}, \mathrm{As}, \mathrm{Ge}, \mathrm{B}$, etc.; $\mathrm{M}=\mathrm{Mo}, \mathrm{W})$.

(1) Berzelius, J. Pogg. Ann. 1826, 6, 369, 380.

(2) (a) Pope, M. T Heteropoly and Isopoly Oxometallates: Springer: Berlin, 1983. (b) Tsigdinos, G. A. Top. Curr. Chem. 1978, 76, 1. (c) Day, V. W.; Klemperer, W. G. Science 1985, 228, 533. (d) Pope, M. T.; Müller. A. Angew. Chem., Int. Ed. Engl. 1991, 30, 34.
Further catalytically important subclasses of the Keggin compounds are the mixed-addenda anions $\mathrm{XM}^{\prime}{ }_{n} \mathrm{M}_{12-n} \mathrm{O}_{40}{ }^{q-}$ (2), where for example $\mathrm{X}=\mathrm{P}, \mathbf{M}^{\prime}=\mathrm{V}$, and $n=1,2$, and the transition metal substituted Keggin compounds $\mathrm{XM}^{\prime}(\mathrm{L}) \mathrm{M}_{11} \mathrm{O}_{39}$ (3), where $\mathrm{M}^{\prime}$ is a transition metal such as $\mathrm{Mn}, \mathrm{Co}, \mathrm{Cu}, \mathrm{Ru}$, etc. and $\mathrm{L}$ is a ligand such as $\mathrm{H}_{2} \mathrm{O}, \mathrm{OH}$, or pyridine, among others.

Interest in heteropoly compounds as homogeneous liquid-phase oxidation catalysts is only a recent development that has been fueled by the inherent stability of these compounds to strongly oxidizing conditions as opposed to other effective and widely studied catalysts such as metalloporphyrins, ${ }^{3}$ which always decompose in the presence of oxidants. ${ }^{4}$ Importantly, it has also

\footnotetext{
(3) Ortiz de Montellano, P. R. Cytochrome P-450; Plenum: New York 1986.

(4) Recently efforts have been made to increase the stability of porphyrins by halogenation of the porphyrin ring: (a) Traylor, T. G.; Tsuchiya, S. Inorg. Chem. 1987, 26, 1339. (b) Traylor, T. G.; Byun, Y. S.; Traylor, P. S.; Bationi,
} P.; Mansuy, D. J. Am. Chem. Soc. 1991, I13, 7821 